\title{
COLOUR HARMONY OF LAND COVER AS INTANGIBLE ENVIRONMENTAL RESOURCE (VOOREMAA LANDSCAPE PROTECTION AREA, ESTONIA)
}

О. О. КАРАСЬов. КОЛЬОРОВА ГАРМОНІЙНІСТЬ ЗЕМНОГО ПОКРИВУ ЯК НЕМАТЕРІАЛЬНИЙ РЕСУРС ДОВКІЛЛЯ (ЛАНДШАФТНА ПРИРОДООХОРОННА ТЕРИТОРІЯ ВООРЕМАА, ЕСТОНІЯ). Кольорова гармонійність довкілля, як привабливе поєднання кольорів земного покриву, є традиційним показником оиінювання мальовничості краєвиду у США. Важливість вивчення кольорів видимого довкілля була відзначена в географї ще близько 100 років тому, але широкого висвітлення ия глибоко географічна проблематика досі не набула. Натомість, теорія і практика кількісного вимірювання кольорової гармонійності як чинника привабливості розвивались у мистеитві, психології та дизайні. Взявщи за основу відповідні добре обгрунтовані здобутки класичних та новітніх науковців, їх було застосовано до даних дистанційного зондування Землі; в результаті земний покрив натурного об'єкту дослідження було диференційовано за показником кольоровоі гармонійності у різні фенологічні періоди для дослідження їі сезонної динаміки. Було встановлено відповідність кольоровоі гармонійності до різних типів земного покриву. Отримані результати можуть бути використані в практиці ландшафтного менеджменту та планування. Багаторічна втрата або набуття земним покривом кольорової гармонійності є перспективним напрямом дослідження сталості діяльності людини у природному довкіллі.

Ключові слова: кольорова гармонійність, земний покрив, дистаниійне зондування Землі, нематеріальні ресурси довкілля

А. О. Карасёв. ЦВЕТОВАЯ ГАРМОНИЧНОСТЬ ЗЕМНОГО ПОКРОВА КАК НЕМАТЕРИАЛЬНЫЙ РЕСУРС ОКРУЖАЮЩЕЙ СРЕДЫ (ЛАНДШАФТНАЯ ПРИРОДОХРАННАЯ ЗОНА ВООРЕМАА, ЭСТОНИЯ). ЦветоваЯ гармоничность окружающей среды, или привлекательное сочетание иветов земного покрова, является традиционным показателем оиенки живописности пейзажа в США. Важность изучения иветов воспринимаемой окружающей среды была отмечена в географии еще около 100 лет назад, но широкого освещееия эта глубоко географическая проблематика до сих пор не получила. В свою очередь, теория и практика количественного измерения иветной гармоничности как фактора привлекательности развивались в искусстве, психологии и дизайне. Взяв за основу соответствующие хорошо обоснованные достижения классических и современных ученых, они были применены к данным дистанционного зондирования Земли; в результате земной покров натурного объекта исследования был дифференцирован по показателю ияветной гармоничности в разные фенологические периоды для анализа ее сезонной динамики. Было установлено соответствие иветовой гармоничности различным типам земного покрова. Полученные результаты могут быть использованы в практике ландшафтного менеджмента и планирования. Многолетняя утрата или приобретение земным покровом иветовой гармоничности является перспективным направлением исследования устойчивости деятельности человека в естественной среде.

Ключевые слова: иветовая гармоничность, земной покров, дистаниионное зондирование Земли, нематериальные ресурсы окружающей среды

\section{Introduction}

\section{Articulation of issue}

The fundamental role of perception in science can hardly be overestimated, and the nature of visual perception imposes constraints on the overall process of cognition. According to different estimations, around $80 \%$ of perceived information is transmitted via sense of vision. In this way, it is not surprising, that the visual perception and, respectively, perception of colours have been in mainstream of geography and environmental science. So, already in the twenties of the last century Russian geographer P. Semyonov-Tyan-Shansky and Finnish geographer J. Granö independently mention colour and other perception phenomena in his books as a subject of geographical research [26; 12]. J. Granö even provides maps of colour patches of environment for particular seasons and dates, and suggests Ostwald's colour system for "chromatological examination of landscape" [12, p. 99]. Later, with progressing global changes in natural environment under the economic and social people's impact, the emphasis shifted upwards the economic role of the measurable visual quality of natural environment and visual values of nature, often connected to the variety of cultural ecosystem services or information functions of landscapes [8]. This trend is discussed in the previous article in more details [6], while here the intangible values of nature are conceptualized in as intangible environmental resources, formalizing both natural and semi-natural environment, perceived visually.

Colours of land cover, as a component of topological visual phenomena of environment, are accessible for study with modern remote sensing (as it will be shown further), so the problem of the given research is to quantify the colouristic harmony of land cover within the study area in Estonia, using known methods of its assessment. To avoid some misconception between the notions of landscape and environment, the landscape here, following the European Landscape Convention and some extent and some leading geographers $[9 ; 2]$, will be understood as a mental image, resulting from a human experience in physical environment, perceived visually. Spectral characteristics of land cover as a part of physical environment served as a scientific object, while their spatial composition - as a subject of the study.

Actual scientific researches and issues analysis

After mentioned above fundamental works by P. Semyonov-Tyan-Shansky and J. Granö, later studies of landscape colours were shifted mostly into a body of landscape architecture, in particular in a seasonal aspect [27], with numerous findings, some of them 
are listed as follows. Landscape preferences increased with increasing of the colour diversity of flowering plants in summer [7]. Increasing of amount and diversity of colours enhances landscape preferences in general [13]. Latest studies still demonstrate the significant role of changing, depending on the season, landscape colours in formation of landscape preferences [25]. Flowering stages of vegetation seasonality are preferred, being strongly determined by physical conditions of the environment [17]. Contemporary landscape studies involve colour already on the roughest level - they are about "blue" and "green" spaces [28; 19]. Colour hues, levels of saturation and brightness matter for emotional response and well-being [19].

Our ability to see colours is based on the sunlight, penetrating the atmosphere of the Earth within so-called atmospheric windows. The sunlight is an electromagnetic radiation (EM radiation or EMR) in some diapason of the electromagnetic spectrum. EMR is characterized with wavelength $(\mathrm{m})$ and frequency $(\mathrm{Hz})$. According to the wavelength, the electromagnetic spectrum is divided into (in ascending order): gamma waves, $\mathrm{X}$-waves, ultraviolet light, visible light, infrared light, microwaves, and radio waves [22]. The part of the spectrum, perceived visually, in most cases varies approximately within $400-700 \mathrm{~nm}$. The cone spectral sensitivity of human eyes is determined by three types of cones, sensitive to three main colours: red, green, blue [29]. That is why the most common colour model, used in electronic devices and remote sensing, consist of the mentioned colours and called RGB. Atmospheric windows, mentioned above, describe diapasons of the electromagnetic spectrum, which could not be caught by Earth atmosphere; one of such windows exists for the range of 300-750 $\mathrm{nm}$ [5]. Thereby, the atmospheric window, allowing the EMR to reach the land surface and land cover, as well as our eyes, belongs to visible light mostly. When the sunlight strikes an object, 5 types of interaction occur: transmission, absorption, reflectance, scattering, emission [15]. Reflected and emitted solar radiation is caught by passive satellite sensor in the quite wide range of the spectrum (including visible diapason) according to the wavelength, and obtained multispectral satellite imagery could be processed for scientific needs. The reflected solar radiation determines the colour of the Earth land cover and land surface. Landsat-7 ETM+ Handbook defines colour as "property of an object, which is dependent on the wavelength of the light, it reflects or, in the case of a luminescent body, the wavelength of the light it emits. If in either case this light is of a single wavelength, the colour seen is a pure spectral colour, but, if the light of two or more wavelengths is emitted, the colour will be mixed" [15, p. 168].
According to S. Bell, several systems of colour modeling have been developed, but they have a three-way organization of hue in common, lightness/value or saturation/chroma [3]. Hue describes the parts of the visible spectrum, while lightness/value and saturation/chroma are dimensions, describing darkness and grayness of each hue respectively. These three-dimensional colour spaces (for example, HSV, HLS, Lab and many others) are capable to precisely enough define each of almost infinite number of colours, while a human eye is able to distinguish only several thousands of them. One of the first and the most commonly used in geography three-dimensional colour systems was developed by Albert Munsell (1915) [21] and it is called after his name. It should be mentioned, that it is based on the human ability to distinguish colours, while other models are rather mathematical idealizations, so for the first time there were decided to use the Munsell's colour model and in further works move to others. This model is still used by US Geological Service (USGS) for a description of soil colours and geological bodies [30] and implemented in satellite imagery processing software, such as ENVI.

Against this background concerning the nature of human colour vision and colour modeling, the applicability of satellite imagery use for purposes of the colouristic study of land cover becomes obvious. For example, multispectral sensor OLI, carried on the satellite Landsat-8, registers reflected solar energy, mentioned above, including Blue, Green and Red parts of the electromagnetic spectrum in the respective bands [31], corresponding to the types of cones, sensitive to these colours in human eyes. The "natural colours" composite of such bands creates a colour model of land cover, similar to the one, visible by human eye from the same height and prospective. Application of multitemporal remote sensing data allows following sometimes dramatic changes in the colours of land cover after the phenological and other changes [15].

There is a wide variety of successful papers, based on colour features of the environment, some of them are referenced further as follows. Colour metrics, derived from Landsat satellite imagery, were used to distinguish burned/non-burned areas [18]. Colour metrics, derived from high-resolution satellite imagery, were used to detect buildings among other urban landscape surfaces [16]. Study of phytoplankton amount in the Gulf of Aden, basing on ocean colour data, provided by ESA Ocean Colour project and low-resolution MODIS data was performed [11]. Soil colour has been found to be easily related to spectral properties when expressed in RGB trichromatic coordinates [10]. Red, green and blue bands of Landsat imagery were converted to HSV colour space to distinguish lithological compo- 
sition of rocks [1]. Temporal water monitoring is possible on the basis of colorimetric data [23]. Colorimetric analysis is also used even for so basic operation, as land cover classification [20]. Provided literature represents only «peeling the first lay of the onion» since the use of transformation of Red, Green and Blue satellite bands into other dimensions is a quite common task in remote sensing and almost all the GIS-packages contain such option for multispectral imagery.

Discretion of unsolved earlier aspects of general issue

Despite the fact of the wide recognition of the colour impact on the landscape values and preferences, human well-being in general, and applicability of remote sensing data for purposes of colour detection, there were no attempts to quantify the colour harmony of the land cover as a component of the environment of the Earth. On the other hand, the notion of colour harmony has been widely discussing in the theory and practice of art, psychology, computer science and other fields, except the environmental science and geography. Indeed, there are several dozens of verified quantitative techniques of colour harmony assessment (mainly for colour pairs or colour in front of another colour as a background), while assessment of colour harmony of visual harmony is still based on the subjective evaluation. The given article begins a study of the colour harmony of visual environment in geography.

The aim of the article is to quantify colour harmony of land cover, using remote sensing data and substantiated techniques. The concept of colour harmony is well-developed throughout last centuries, and nowadays it is proven to be homogeneous and universal enough to design computational models, that would predict, to some extent, landscape values, preferences and people's outdoor behaviour, activities as cultural ecosystem (or landscape) services.

\section{Presentation of the main material \\ Data and methods}

Radiometrically calibrated and atmospherically corrected Landsat-8 OLI image for 14.06.2016 and 20.10.2016 were used in the given study to compute the colour harmony scores for land cover within Vooremaa Landscape Protection Area (in Estonia), comparing to each other in terms of different phenological phases (the beginning of the growing period and its ending). Imagery were converted into the Munsell colour space, consisting of three dimensions: Hue (the colour itself - Blue, Green, Red, Magenta etc.), Chroma (Saturation, or colour purity; briefly could be described as an amount of gray in Hue), Value (Lightness, or, roughly, amount of white in Hue). Albert Munsell intuitively developed his own criterion of colour harmony
(1921) [4]. He proposed to keep the balance between the colour strength of particular hue (product of value and chroma in his colour system) and the area of this hue:

$$
\sum_{n=1}^{M} C S_{n} \cdot A_{n}=0,
$$

where $M$ is the total number of colours within some zone or floating circle; $C S_{n}-$ colour strength, calculated as chroma of colour $n \times$ value of colour $n$; $A_{\mathrm{n}}$ is the area of colour $n$. The floating circle of 21 pixels in size was used as a compromise to keep the homogeneity of land cover units against their diversity. Results of the modeling, rescaled from 0 to 1 values are on fig. 1 (colour harmony decreases from 0 to 1). Note the inverse relationship: the colour with the lower color strength should be is assigned to the larger visual area to create colour harmony.

Schloss \& Palmer conducted empirical experiments to distinguish colour harmony values from colour preferences (many other authors did not pay a sufficient attention to this problem) [24]. They revealed several regularities, and one of the most generals is that colour pairs, more similar in hue and with lower saturation, tend to be harmonious. Hue similarity was calculated as Haralick's Homogeneity function of Grey Level Co-Occurrence Matrix [14], then the resulting harmony model was computed, using Fuzzy overlay analysis in ArcGIS 10.4.1 (results in scale from 0 to 1 are on fig. 2, colour harmony increases from 0 to 1 ).

\section{Results and discussion}

Analysis of the localities with different band composites shows, that water bodies, forests and wetlands have the highest scores of both colour harmonies, while some crop fields (mainly with saturated young vegetation and open soil) have the lowest colour harmony scores. Munsell's colour harmony technique is sensitive to the one type of crops only, colour harmony after Schloss \& Palmer seem to be more adequate and applicable. However, both techniques show similar results in differentiation of land cover, taking into consideration, that Munsell's score was calculated with a floating circle of 21 pixels in diameter and reflects mainly areas, "disharmonious" in colours. According to the Munsell's model for the different stages of cropping season, the area of disharmonious colouristically areas of land cover increases in autumn (mainly because of the colour of open soil as a result of crop harvesting). Models after Schloss \& Palmer also show the tendency to the decreasing of the colour harmony of land cover with an increasing of colour contrasts in the end of the cropping season. Anyway, two selected models provide the objective quantitative indicator of the colour harmony of the visual environment, so in close prospective, it would allow a permanent monitoring of its loss and gaining 
Colour Harmony of Land Cover (Munsell, 1921) Vooremaa Landscape Protection Area, 14.06.2016

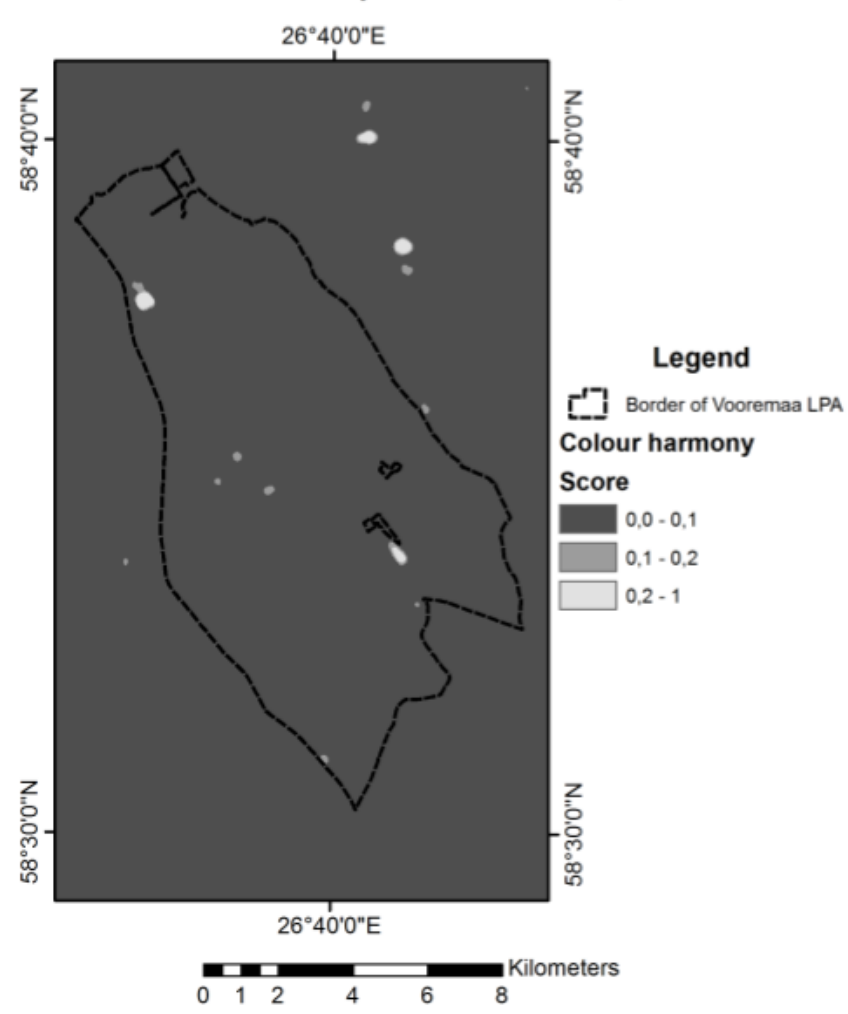

Colour Harmony of Land Cover (Munsell, 1921) Vooremaa Landscape Protection Area, 20.10.2016

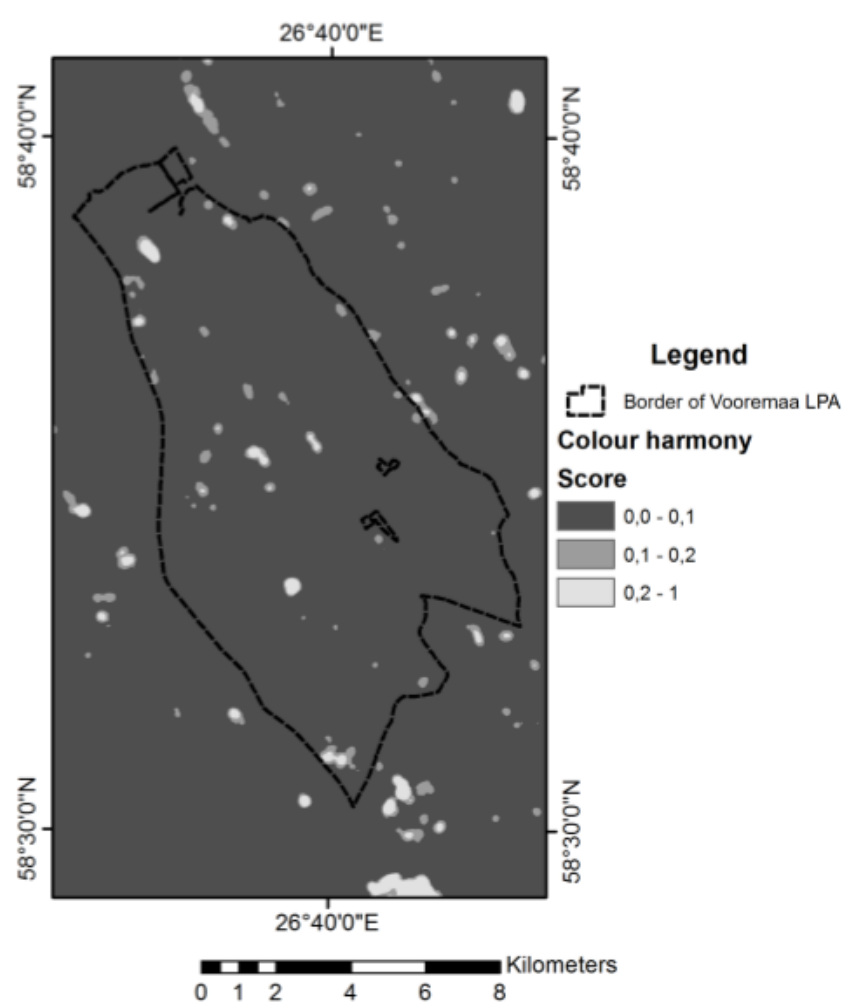

Fig. 1. Maps of colour harmony scores for land cover (inverted Munsell's score)

Colour Harmony of Land Cover (Schloss \& Palmer, 2011) Vooremaa Landscape Protection Area, 14.06.2016

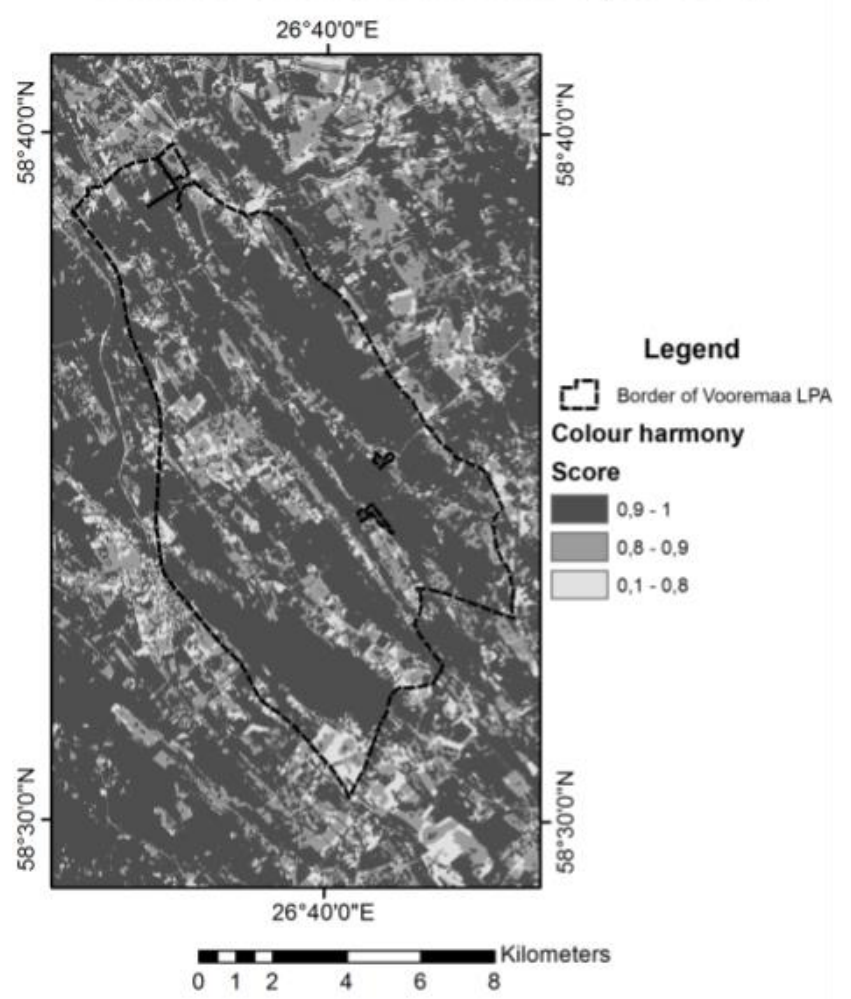

Colour Harmony of Land Cover (Schloss \& Palmer, 2011) Vooremaa Landscape Protection Area, 20.10.2016

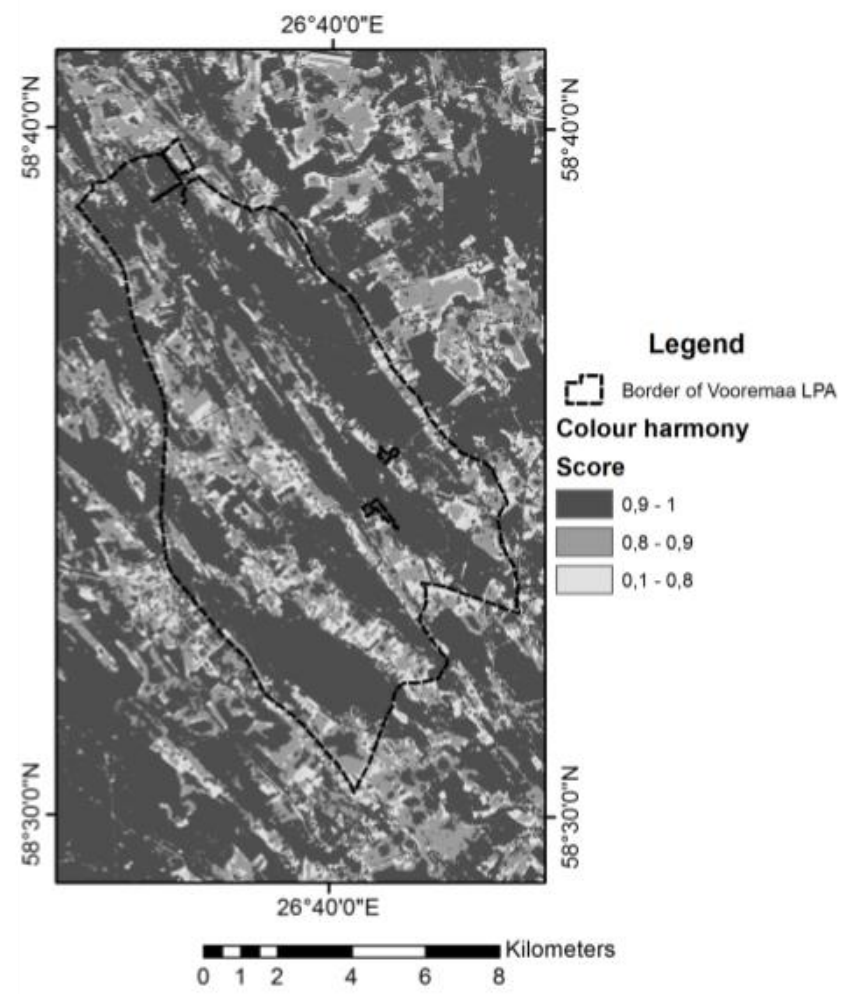

Fig. 2. Maps of colour harmony scores for land cover (Schloss \& Palmer scores)

according to the natural variability, combined with the sustainability of people activities. Obviously, those discussed models represent the colour harmony in different details (Munsell's model is 
very generalized), and there are other authors, providing principally different models of colour harmony score computation. They should be taken into account in the further papers.

Of course, the obtained results are delimitated with abilities of satellite sensors. Firstly, the physical environment is changing permanently, and the frequency of remote data producing is not sufficient enough to catch the diurnal dynamics and even seasonal one entirely; however, we are able to model the colour dynamics on the most expressive stages of the development of the environment. Secondly, the sky colour appearance, responsible for the half of the visual scene is beyond the scope of this study. Thirdly, remote sensing data provides the horizontal projection only, while visual perception is obviously different and a further combination of both in-situ and remote approaches would enrich the results. Fourthly, the spatial resolution of the remote sensing data (for example, 15 metres for used pan-sharpened Landsat-8) does not allow to fixate the details of colour harmony (flowers, separate trees, and houses, etc.), so the colour harmony scores are scaledependent. Despite all the mentioned restrictions, remote sensing techniques, widely used for other geographic tasks, seem to be very promising for detection and monitoring of colour harmony of land cover as an important dimension of intangible environmental resources. What is more, J. Granö argues, that mapping of environment for purposes of landscape examination must imply not only areas, seen from a particular viewpoint, but all some area as a whole [12], so the problem of mismatch between human visual field on the ground and satellite imagery scene is eliminated within geographical study.

\section{Conclusions}

To sum up, the given paper describes the scores of the colour harmony of land cover within the study area in Estonia, basing on the non-controversial and reliable enough criteria of colour harmony from theories of colour and psychology of perception. The potential of remote sensing use for the purposes of colour harmony modeling is presented and discussed. During the steps of analysis of satellite imagery, some correspondence between the range of colour harmony score and types of land cover is revealed. These primary results allow putting forward a hypothesis about the regular relationships between physical and cultural characteristics of the environment (such as greenness, wetness, soil quality, distance to the roads, settlements, farms and forests), and colour harmony scores. What is more, findings of different authors would enrich ways of possible computation of colour harmony of land cover. Thereby, the prospects for the development of such direction of geography, closely related to the art, theories of perception and environmental psychology, are obvious. It is especially true in view of practical needs of landscape management and planning; the proposed techniques would allow measuring precisely the extent of loss or gaining of colour harmony as a result of co-action of natural and cultural agents, so within the concept of so-called weak sustainability it would be possible to overcome the underestimation of the loss of natural capital for purposes of increasing of human prosperity and develop ways of compensation to preserve the natural beauty of the nature.

\section{Acknowledges}

This research was supported by European Social Fund's Dora Plus Programme

\section{References}

1. Amer R. Image processing and analysis using Landsat ETM imagery for lithological mapping at Fawakhir, Central Eastern desert of Egypt [Електронний ресурс] / R. Amer, T. Kusky, P. C. Reinert [ma iн.] // ASPRS 2009 Annual Conference, Baltimore, Maryland. - 2009. - Pежим доcmyny: http://info.asprs.org/publications/proceedings/ baltimore09/0006.pdf. - Дата звернення: 08.06.2017.

2. Antrop M. Geography and landscape science [Електронний pecypc] / M. Antrop // Belgeo. Revue belge de géographie. - 2009. - № 1-2-3-4. - C. 9-36. - Режим достуny: http://belgeo.revues.org/13975. - Дата звернення: 08.06.2017.

3. Bell S. Elements of visual design in the landscape /S. Bell. - London and New York: Taylor \& Francis, 2004. - 224 c.

4. Chamaret C. Color harmony: experimental and computational modeling : дис. канд. наук : Image Processing / C. Chamaret-Rennes, 2016. - $210 \mathrm{c}$.

5. Chapana R. S. The Relative Influence of Solar Radiative and Solar Geomagnetic Variation on the Dynamics of the Polar Upper Mesosphere / R. S. Chapana. - Trondheim, 2012. - 54 c.

6. Chervanyov I. The intangible natural resources (INR) in the aspects of natural capital of new geography: some perspectives for Ukraine [Електронний ресурс] / I. Chervanyov, О. Кагаsov // Вісник Харківського національного університету імені В. Н. Каразіна, серія «Геологія. Географія. Екологія». - 2015. - № 42. - С. 106-110. Режим достуny: http://periodicals.karazin.ua/geoеco/article/viewFile/3743/3310. - Дата звернення: 08.06.2017.

7. Clay G. R. Scenic landscape assessment: the effects of land management jurisdiction on public perception of scenic beauty / G. R. Clay, T. C. Daniel // Landscape and urban planning. - 2000. - № 1. - C. 1-13.

8. De Groot R. A typology for the classification, description and valuation of ecosystem functions, goods and services / R. de Groot, M. A. Wilson, R. M. Boumans // Ecological economics. - 2002. - № 3. - C. 393-408. 
9. Déjeant-Pons M. The European landscape convention [Електронний ресурс] / M. Déjeant-Pons // Landscape Research. - 2006. - № 4. - C. 363-384. - Режим достуny: http://orcp.hustoj.com/wp-content/uploads/2016/03/2006The-European-Landscape-Convention.pdf. - Дата звернення: 08.06.2017.

10. Escadafal R. Munsell soil color and soil reflectance in the visible spectral bands of Landsat MSS and TM data / R. Escadafal, M. C. Girard, D. Courault // Remote Sensing of Environment. - 1989. - № 1. - C. 37-46.

11. Gittings J. A. Seasonal phytoplankton blooms in the Gulf of Aden revealed by remote sensing [Електронний pecypc] / J. A. Gittings, D. E. Raitsos, M. F. Racault [ma iн.] // Remote Sensing of Environment. - 2017. - T. 189. C. 56-66. - Режим доступу: http://repository.kaust.edu.sa/kaust/handle/10754/623168. - Дата звернення: 08.06.2017.

12. Granö J. G. Pure geography/J. G. Granö. - Baltimore, MD: Johns Hopkins University Press, 1997. - 194 c.

13. Hands D. E. Enhancing visual preference of ecological rehabilitation sites [Електронний pecypc] / D. E. Hands, R. D. Brown // Landscape and Urban Planning. - 2002. - № 1. - C. 57-70. - Режим доступу: http://atrium.lib.uoguelph.ca/xmlui/bitstream/handle/10214/4032/Hands_Brown_2002.pdf?sequence=6\&isAl. Дата звернення: 08.06.2017.

14. Haralick R. M. Textural features for image classification [Електронний ресурс] / R. M. Haralick, K. Shanmиgam // IEEE Transactions on systems, man, and cybernetics. - 1973. - № 6. - C. 610-621. - Режим доступу: http://haralick.org/journals/TexturalFeaturesHaralickShanmugamDinstein.pdf. - Дата звернення: 08.06.2017.

15. Irish R. Landsat 7 science data users handbook [Електронний ресурс] / R. Irish // National Aeronautics and Space Administration, Report. - 2000. - Режим docmyny: https://landsat.gsfc.nasa.gov/wp-content/uploads/2016/08/ Landsat7_Handbook.pdf. - Дата звернення: 08.06.2017.

16. Jabari S. Stereo-based building detection in very high resolution satellite imagery using IHS color system / S. Jabari, Y. Zhang, A. Suliman // Geoscience and Remote Sensing Symposium (IGARSS), 2014 IEEE International. 2014. - C. 2301-2304.

17. Junge X. Aesthetic quality of agricultural landscape elements in different seasonal stages in Switzerland [Eлектронний ресурс] / X. Junge, B. Schüpbach, T. Walter [ma ін.] // Landscape and Urban Planning. - 2015. - T. 133. - C. 67-77. - Режим достуny: https://www.researchgate.net/profile/Bernhard_Schmid/publication/ 266833258_Aesthetic_quality_of_agri._-Дата звернення: 08.06.2017.

18. Koutsias N. The use of intensity-hue-saturation transformation of Landsat-5 Thematic Mapper data for burned land mapping [Електронний ресурс] / N. Koutsias, M. Karteris, E. Chuvico // Photogrammetric Engineering and Remote Sensing. - 2000. - № 7. - C. 829-840.

19. Lengen $C$. The effects of colours, shapes and boundaries of landscapes on perception, emotion and mentalising processes promoting health and well-being [Електронний ресурс] / C. Lengen // Health \& place. - 2015. - № T. 35. C. 166-177. - Режим достуny: https://www.researchgate.net/profile/Charis_Lengen/publication/ 279737636_The_effects_of_colours_shap._-Дата звернення: 08.06.2017.

20. Lessel J. Creating a basic customizable framework for crop detection using Landsat imagery / J. Lessel, P. Ceccato // International Journal of Remote Sensing.-2016.- № 24.- C. 6097-6107.

21. Munsell A. H. Atlas of the Munsell color system / A. H. Munsell. - Wadsworth: Howland \& Company, Incorporated, Printers, 1915. - $42 \mathrm{c}$.

22. NASA (2013). The Electromagnetic Spectrum [Електронний ресурс] / NASA. - 2013. - Режим доступу: https://imagine.gsfc.nasa.gov/science/toolbox/emspectrum2.html. - Дата звернення: 08.06.2017.

23. Pekel J. F. A near real-time water surface detection method based on HSV transformation of MODIS multi-spectral time series data /J. F. Pekel, C. Vancutsem, L. Bastin [ma iн.] // Remote sensing of environment. - 2014. - T. 140. C. 704-716.

24. Schloss K. B. Aesthetic response to color combinations: preference, harmony, and similarity [Електронний ресурс] / K. B. Schloss, S. E. Palmer // Attention, Perception, \& Psychophysics. - 2011. - № 2. - C. 551-571. - Pежuм доcmyny: https://www.ncbi.nlm.nih.gov/pubmed/21264737. - Дата звернення: 08.06.2017.

25. Schüpbach B. Seasonality, diversity and aesthetic valuation of landscape plots: An integrative approach to assess landscape quality on different scales / B. Schüpbach, X. Junge, P. Lindemann-Matthies [ma iн.] // Land Use Policy. - 2016. - № T. 53. - C. 27-35.

26. Semyonov-Tyan-Shansky V. P. Rayon i Strana /V. P. Semyonov-Tyan-Shansky. - M; L.: GIZ, 1928. - 312 c.

27. Stobbelaar D. J. Seasonality of agricultural landscapes: reading time and place by colours and shapes / Stobbelaar D. J., Hendriks K. - Springer, 2007. - 103-126 c. - (Seasonal landscapes). - ISBN 978-1-4020-4990-3.

28. Swetnam R. D. Quantifying visual landscape quality in rural Wales: A GIS-enabled method for extensive monitoring of a valued cultural ecosystem service [Електронний pecypc] / R. D. Swetnam, S. K. Harrison-Curran, G. R. Smith // Ecosystem Services. - 2016. - Pежuм доcmyny: http://www.sciencedirect.com/science/article/pii/ S2212041616304533. - Дата звернення: 08.06.2017.

29. Toolson E. Human Cone Action Spectra [Електронний pесурс] / Eric Toolson - Pежим доступу: https://www.unm.edu/ toolson/human_cone_response.htm. - Дата звернення: 08.06.2017.

30. USGS. Munsell Color Code [Електронний ресурс] / USGS // U.S. Geological Survey Open-File Report $2006-1195$. - 2014. - Режим доступy: https://pubs.usgs.gov/of/2006/1195/htmldocs/munsellcode.htm. - Дата звернення: 08.06.2017.

31. Zahter K. Landsat 8 (L8) data users handbook [Електронний ресурс] / K. Zahter // EROS. - 2016. - Pежим доcmyny до pecypcy: https://landsat.usgs.gov/sites/default/files/documents/Landsat8DataUsersHandbook.pdf. 